\title{
ИMEHA. ПOРTPETЫ
}

УДК 76.036(47)(092)Бенуа А.Н.

ББК 85.103(2=411.2)53-8Бенуа А.Н.,43

DOI 10.25281/2072-3156-2019-16-2-184-195

\section{A.Е. ЗАВЬЯЛОВА}

\section{ПРОИЗВЕДЕНИЯ \\ АЛЕКСАНДРА ДЮМА \\ В ТВОРЧЕСТВЕ \\ АЛЕКСАНДРА БЕНУА}

\section{Анна Евгеньевна Завьялова,}

Российская академия художеств,

НИИ теории и истории изобразительных искусств, отдел русского искусства XVIII - начала XX в., ведущий научный сотрудник

Пречистенка ул., д. 21, Москва, 119034, Россия

кандидат искусствоведения

ORCID 0000-0003-2704-0486; SPIN 6024-1129

E-mail: annazav@bk.ru

Реферат. Исследуется проблема интерпретации литературного источника в визуальном творчестве А.Н. Бенуа. Выявлены и проанализированы новые источники его произведений: исторические романы А. Дюма-отиа. Вопрос о роли романов А. Дюма, посвященных истории Франции XVII и XVIII столетий, в творчестве А. Бенуа никогда не становился объектом исследования, этим фактом определяется актуальность данной статьи. Научная новизна работы заключается в выявлении новых литературных источников творчества А. Бе- нуа: романов Дюма «Жозеф Бальзамо (Записки врача)», (1846-1848); «Людовик XIV и его век» (1844); «Людовик XV и его эпоха» (1849) и установлении параллелей между ними и изобразительной практикой художника: живописью, графикой и искусством оформления книги. Автор анализирует содержание воспоминаний художника, его литературных произведений и дневников, а также дневников Е. Лансере и дополняет эти сведения сравнительным текстологическим анализом воспоминаний А. Бенуа и романов А. Дюма в русскоязычных переводах. Этот метод позволяет углубить формальный анализ произведений А. Бенуа (в первую очередь двух Версальских серий) и отчасти раскрыть механизм сложного образного синтеза в художественном сознании на рубеже XIXXX столетий, на основе которого они создавались, расширить существующие представления о литературных источниках творчества художника. Автор делает вывод о том, что романы Дюма «Жозеф Бальзамо», «Людовик XIV и его век» оказали влияние на восприятие художником темы придворной культуры и Версаля в 
историческом, культурном и природном аспектах. Это выразилось в обращении к сюжету «кормления рыб» в конце 1890-х г2., в формировании образов Версаля и короля Людовика XIV в старости. Установлено, что роман «Жозеф Бальзамо» повлиял на создание Бенуа образа повседневного Трианона в прошлом. Тогда же под влиянием романа «Людовик XV и его эпоха» художник обратился к трактовке образа маркизы де Помпадур как «султанши». Кроме того, три мушкетера - герои одноименного романа Дюма, помещены в рисунок титульного листа альбома Бенуа «Версаль». При этом важно, что речь идет не о прямом иллюстрировании романов, а именно о творческом процессе создания образной системы и становления стилистики художника.

Ключевые слова: Теория и история искусства, искусствоведение, художественная культура, русское искусство конца XIX - первой половины XX в., А. Бенуа, пейзаж, модерн, А. Бёклин, А. Дюма, Версаль, Трианон, Людовик XIV, маркиза де Помпадур.

Для цитирования: Завъялова А.Е. Произведения Александра Дюма в творчестве Александра Бенуа // Обсерватория культуры. 2019. Т. 16, № 2. C. $184-195$. DOI: $10.25281 / 2072-3156-$ 2019-16-2-184-195.

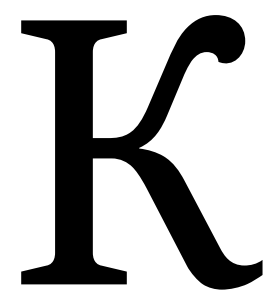

руг произведений художественной литературы, повлиявших на изобразительное творчество А. Бенуа, необычайно широк. Он включает прозу и поэзию французских, немецких, бельгийских, датских литераторов, из книг которых художник, сознательно или нет, черпал темы, сюжеты, мотивы и образы для своих рисунков и картин. Еще обширнее были его читательские интересы, к которым он сам относил, в частности, книги А. Дюма-отца, автора знаменитых романов на сюжеты из истории Франции XVII века. Вспоминая на склоне лет свои гимназические годы, Бенуа заметил на страницах мемуаров, что тогда «зачитывался романами Дюма» [1, с. 407]. Сопоставление этого замечания с данными из других литературных работ Бенуа, а также со свидетельствами его друзей позволяет увидеть, что романы Дюма повлияли на формирование образов Версаля и старого короля Людовика XIV в творчестве художника, а также предопределили его обращение к ряду сюжетов. Тем не менее данный вопрос еще не привлекал специального внимания исследователей и ставится в данной работе впервые.

Вступительная статья Бенуа к альбому литографий «Версаль» (Петербург ${ }^{1}$, издательство «Аквилон», 1922), составленному преимущественно из его версальских этюдов 1905-1906 гг., содержит более подробные, чем в мемуарах, сведения об отроческом чтении романов Дюма и о впечатлении, которое они на него произвели. «О Версале я слыхал и виды его видел еще в раннем детстве, но познакомился с ним ближе, когда мне было 13 лет и когда я украдкой зачитывался томиками Александра Дюма, наполнявшими запретные для меня задние ряды отцовской библиотеки. До тех пор Версаль был одной из бесчисленных диковин заграницы, с этого же момента я открыл в себе, что связан с ним какой-то личной связью, что он мне “родной”. Вчитываясь в эти пленительные небылицы, мне казалось, что я издавна знаком со всем сценарумом, в котором протекает волнующее действие "Joseph Balsamo" и "Collier de la Reine”. И то же ощущение чего-то лично близкого, “родного” я почувствовал в еще большей степени, когда впервые наяву ступил на хрупкий гравий садовых площадей и улиц Версаля ...» [2, с. 11].

Напомним, что творчество А. Дюма почти с самого начала, т. е. с 1830-х гг., было популярно в России, однако при этом отношение к нему не было однородным. Так, на протяжении 1850-1860 гг. сложилось мнение о романах Дюма как о легком и, соответственно, неполезном чтении [3, с. 491]. Возможно, именно этими соображениями был продиктован родительский запрет на книги Дюма для юного Шуры Бенуа. Тем не менее к середине XIX столетия многие произведения Дюма, в том числе и те, которые привлекли особое внимание Бенуа, были переведены на русский язык. Однако это не исключает знакомства будущего художника с ними в оригинале.

${ }^{1}$ В это время город официально назывался Петроградом, но в изданиях «Аквилона»-Петербург. 
Действие романов А. Дюма «Жозеф Бальзамо» и «Ожерелье королевы» (1849-1850), упомянутых в статье А. Бенуа, разворачивается во время правления королей Людовика XV и Людовика XVI. Каждая книга содержит большое количество описаний повседневной жизни Версаля при этих правителях. Так, значительная часть действия романа «Жозеф Бальзамо» происходит в дворцовом ансамбле Трианон (который входит в дворцово-парковый ансамбль Версаля), преимущественно в небольшом дворце Малый Трианон, построенном по приказу Людовика $\mathrm{XV}$ для частной жизни короля.

Отголосок увлечения Бенуа этим романом можно уловить среди его версальских этюдов, выполненных весной 1906 года в Трианоне. «Божественный день. <..> Днем ходил с детьми в Трианон, где начал этюд “Зеркальца” со ступеней дворца», - записал художник в дневнике 5 марта 1906 г. [4, с. 88], а на следующий день он засвидетельствовал, что «днем кончил удачно “Зеркальце” [4, с. 89]. В акварельный этюд «Версаль. Трианон» (1906, Вологодская областная картинная галерея) с изображением Лесного флигеля Большого Трианона на фоне бассейна «Зеркало» (другое его название «Плафон») художник поместил две стаффажные фигуры мужчины и женщины в костюмах XVIII столетия, разговаривающих на ходу. Судя по чепчику женщины, она принадлежит к челяди дворца, которая активно участвовала в жизни своих господ.

Изобразив незначительную бытовую сценку так, словно ее увидел случайный прохожий, он создал достоверный образ повседневного Версаля полуторавековой давности. Эта сцена отвечает многим эпизодам из романа «Жозеф Бальзамо», но при этом ни с одной из них не связана напрямую: иллюстрирование явно не входило в задачу художника. Это произойдет позднее, в середине 1900-х гг. во время второго двухлетнего пребывания А. Бенуа во Франции. Пока же, в конце октября 1896 г., оказавшись впервые в Версале, он поразился несоответствию своего реального впечатления тому, которое сложилось у него еще в детстве благодаря книгам и гравюрам. «В Петербурге мне казалось, что и Версаль я отлично знаю и, отправляясь туда, я был уверен, что ничего совершенно для себя неожиданного я там не най- ду. Однако и тут вышло совсем иначе. Именно таким, каким Версаль предстал тогда, я никак не думал его увидеть. Я не думал, что он до того грандиозен и в то же время исполнен какой-то чудесной меланхолии... Что-то даже грандиозное и трагическое чудилось мне как в самом дворце, так и в садах в тот мрачный ноябрьский вечер...», - вспоминал художник на страницах мемуаров [5, с. 120]. Это описание перекликается с образом зимнего Версаля из романа Дюма «Жозеф Бальзамо»: «Величественный и холодный Версаль с его огромными деревьями, многие из которых уже начинали сохнуть и умирать от старости, поразили юношу тем чувством священной печали, перед каким не может устоять ни один человек с тонкой душевной организацией при виде величия, созданного упорным трудом человека или всемогущей природой» [6, с. 330-331]. Этот вербальный образ совпадает с юношеским визуальным восприятием А. Бенуа черно-белого воспроизведения картины А. Бёклина «Остров мертвых» (1883, местонахождение неизвестно) на страницах журнала Die Kunst für Alle. C него началось знакомство Бенуа с искусством швейцарского мастера, переросшее в увлечение [7, с. 421-422]. Картина привлекла его «строгой и печальной поэзией» [1, с. 673]. Ее черные кипарисы напомнили о себе осенним вечером в Версале, когда молодого художника «особенно поразили черные конусы и кубы стриженных туй и зеркальность бассейнов» [5, с. 120]. Свое впечатление он зафиксировал в этюде темперой «Вид на лестницу и террасу в Версале» (1896, Государственный Русский музей, ГРМ). Это очень темный, выполненный на закате пейзаж: четкие силуэты конусов подстриженных деревьев и ваз на балюстраде террасы выглядят особенно выразительно и даже декоративно в последних отблесках заходящего солнца на фоне далекого, еще светлого неба. И по образному, и по художественному решению этюд перекликается с картиной Бёклина «Остров мертвых», которая, в сочетании с описанием Дюма, повлияла на облик парка, сложившийся у Бенуа. «То не был Версаль веселых празднеств Короля-Солнца и то не была прекрасная декорация для тех романтических авантюр, которые здесь разыгрывались. Почему-то я сразу перенесся в последние годы 


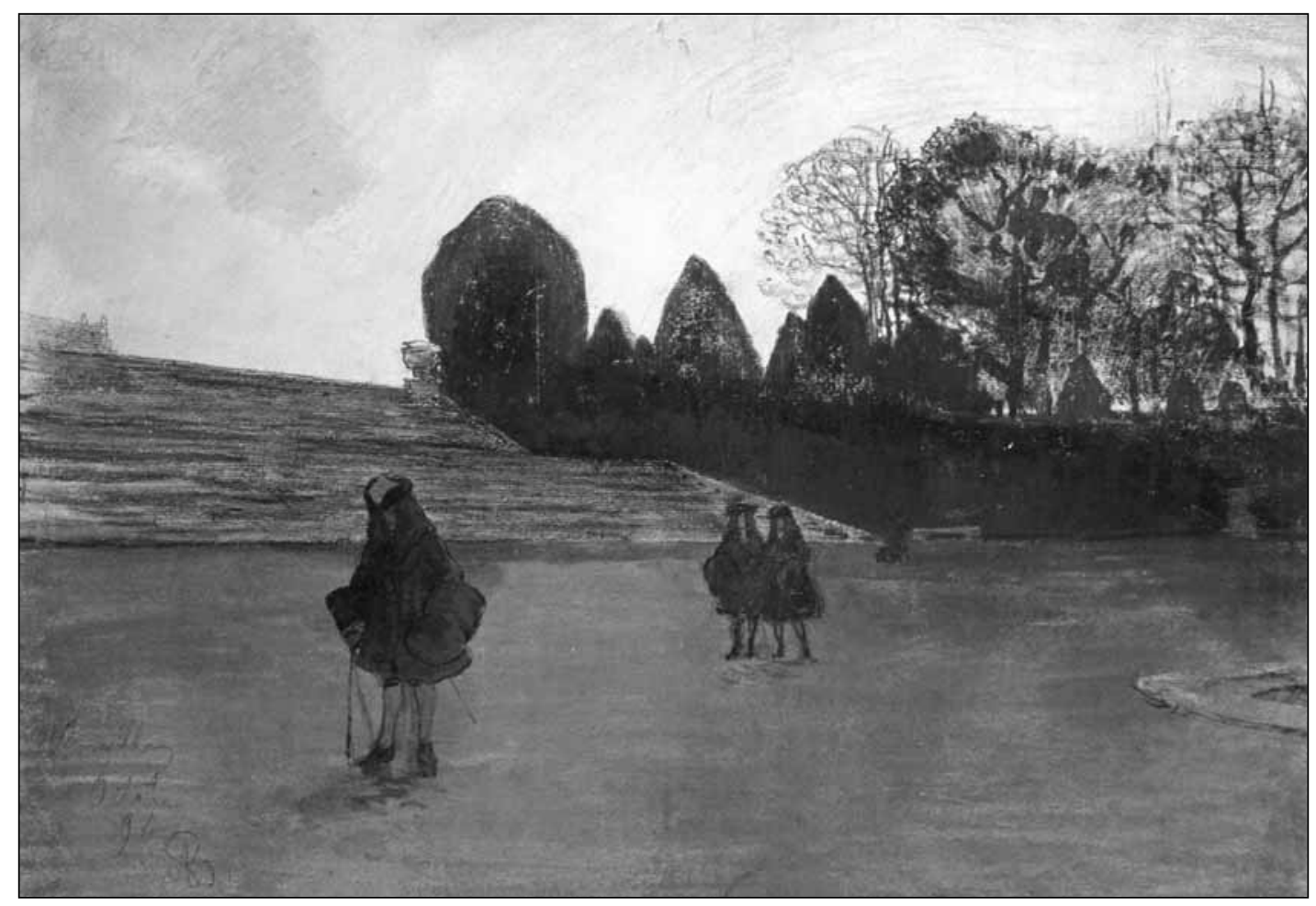

Рис. 1. А. Бенуа. Прогулка короля. 1896.

Картон, пастель, гуашь. Государственный Русский музей

царствования Людовика XIV», - вспоминал художник на страницах мемуаров [5, с. 120]. Более того, он признался, что «почему-то представился он (Людовик XIV. - A. 3.) не в виде юного красавца-полубога, любовника блестящих женщин, мощного триумфатора и устроителя баснословных празднеств, но увидел я его на склоне лет, больным и хилым, ищущим одиночества, разочарованного в людях и собственном величии» [5, с. 182-183].

Нет оснований сомневаться в искренности мемуариста, однако его обращение к последним годам правления Людовика XIV в осеннем Версале, исполненном печальной поэзии, неслучайно. Старость короля, уставшего и разочарованного, очень образно описана в романе-хронике «Людовик XIV и его век» Дюма: «Людовик XIV не имел сил сопротивляться своей дряхлости, и единственным движением, на которое он соглашался, были поездки в маленькой ручной коляске по великолепным версальским садам, ставшим такими же печальными, как и их хозяин. Черты лица короля обнаружили страдания, которые он молча - слишком гордый, чтобы жаловаться - ис- пытывал в холодном величии последних дней» [8, с. 754].

Судя по свидетельству дневника Е. Лансеpe, друга и племянника Бенуа, дядя уже в декабре 1896 г., то есть всего через два месяца после своего приезда во Францию, советовал ему читать Дюма, в том числе "Siècle de Louis XIV, $\mathrm{XV}$ ” для изучения старого Парижа [9, с. 336337]. Речь шла, очевидно, о романах-хрониках «Людовик XIV и его время» и «Людовик XV и его эпоха», с которыми Бенуа познакомился еще в Петербурге.

Рассматривая влияние романа-хроники Дюма на формирование образа Людовика XIV в творчестве Бенуа в конце 1890-х гг., не стоит говорить о сознательном обращении художника к тексту: услужливая и поистине бездонная память творца предоставляла ему воспоминания, отвечающие свежим впечатлениям. На основе их синтеза возникал образ, который нередко становился основой творческого замысла. Именно так произошло в данном случае. После первого посещения Версаля осенью 1896 года Бенуа, по его признанию, задумал и «набросал картину, в которой среди почер- 


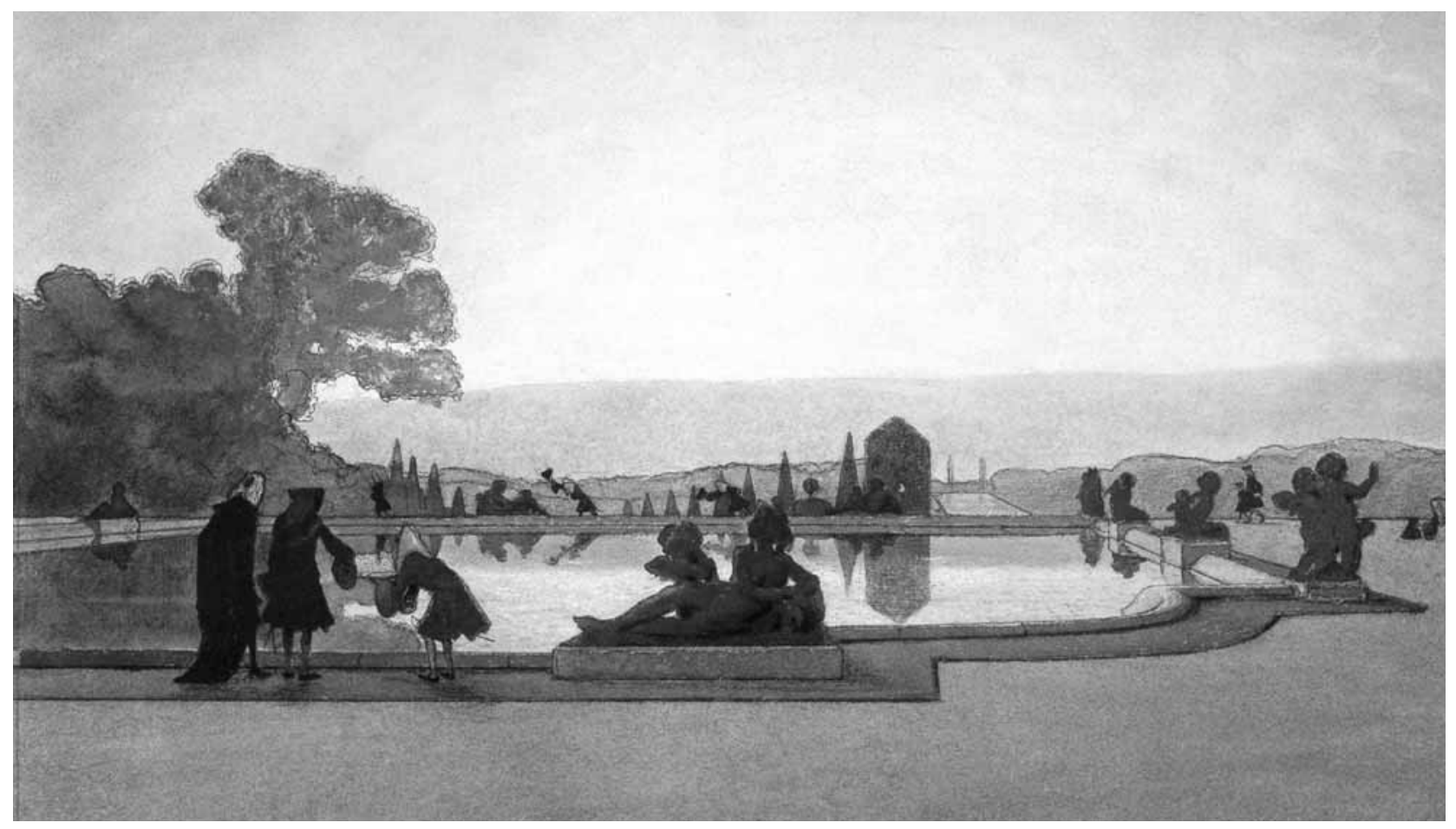

Рис. 2. А. Бенуа. У бассейна Цереры (Людовик XIV кормит рыб). 1897. Из серии «Последние прогулки Людовика XIV».

Бумага, акварель, гуашь. Государственный Русский музей

невших и оголенных садов на террасе Латоны выступает одетый в зимние одежды король, окруженный несколькими приближенными: $<$...> Мне всюду мерещилась эта самая, чуть согбенная, но все же еще величественная фигуpa, то тяжело ступающая, опершись на трость, то сидящая в золоченом колоссальном кресле» [5, с. 183]. Этюд «Прогулка короля» (1896, ГРМ) в сложной технике из пастели и гуаши (рис. 1), в котором изображена одинокая фигура короля в вечернем парке на фоне темных конусов подстриженных деревьев, является, по всей видимости, одним из набросков будущей картины, замысел которой не был реализован. Этюд подписан октябрем 1896 года, поэтому можно утверждать, что Бенуа впервые посетил Версаль не ноябрьским, как он написал в мемуарах много лет спустя, а поздним октябрьским вечером.

Новый замысел картины о Людовике XIV на склоне лет оформился у художника, по его признанию, только поздней осенью 1897 года, когда он «отважился затеять картину, в которой суммировал бы» свои версальские впечат- ления [5, с. 183]. Темой для будущей картины он выбрал эпизод, в котором «“Луи Каторз” предавался своему любимому развлечению, а именно - кормлению рыб в разных водоемах своей резиденции» [5, с. 183]. Забегая вперед заметим, что и этот замысел не был реализован, но на пути к нему Бенуа создал работы в сложной технике из акварели и гуаши: «Людовик XIV. Кормление рыб» и «У бассейна Цереры (Людовик XIV кормит рыб)» (оба - 1897, ГРМ) (рис. 2.), «Бассейн Цереры» (1897, Государственная Третьяковская галерея).

Их значимость для эволюции творчества художника и русского искусства рубежа XIX - XX вв. в целом определяется тем, что эти листы являются наглядным свидетельством интенсивных творческих поисков Бенуа. Он обращался к самым разным источникам, от рисунков для гравюр на дереве А. Менцеля до ксилографий японских мастеров XVIII-XIX вв. школы «укиё-э» и журнальной графики немецких мастеров конца XIX - начала XX в. [10, с. 75-78]. Синтез впечатлений, оставленных ими, французским ис- 
кусством XVIII столетия (в том числе пейзажей Ю. Робера и гравированных видов Жака и Жана Риго), а также собственными натурными этюдами в парке воплотился в создании вышеназванных произведений Бенуа, запечатлевших начало становления стиля модерн в его искусстве.

Выбор темы кормления карпов у Бенуа опять же не был случайным. Это развлечение французских королей очень жизненно описано на страницах романа «Жозеф Бальзамо», где ему предавался Людовик XV: «Вскоре вернулся лакей, неся на блюде японского фаянса большой круглый хлеб, в который был воткнут длинный острый нож. Удовлетворенный король сделал лакею знак следовать за ним и направился к пруду. Кормить карпов уже стало семейной традицией. Людовик XIV ежедневно развлекался этим» [6, с. 275]. В романе «Людовик XIV и его век» Дюма, описывая старость короля, также заметил, что он «забавлялся кормлением карпов в пруду, а придворные созерцали это с благоговейным удивлением» [8, c. 734]. Кстати, эти эпизоды совпали с детскими воспоминаниями Бенуа. В возрасте шести лет будущий художник очень любил наблюдать на даче в Петергофе, как старик-лакей кормил золотых рыбок в пруду около Марли: «Забавно было глядеть, как сотни этих рыбок устремлялись на крошки хлеба, бросаемые старым-старым дворцовым лакеем. Чтобы привлечь к берегу рыбок, он звонил в колокольчик, и тотчас же массы сверкающих золотом обжор являлись и расхватывали хлеб» [1, с. 269].

Здесь нужно отметить, что Бенуа на протяжении всей жизни очень ценил свои детские воспоминания. Он сам признал это в зрелые годы на страницах дневника (1922), пережив тяготы первых послереволюционных лет [11, c. 473]. Именно в это время, работая над альбомом «Версаль», художник поместил в рисунок для титульного листа с изображением Лестницы ста ступеней трех мушкетеров героев одноименного романа Дюма, с которым он, очевидно, познакомился в отрочестве. Вряд ли есть основания считать, что Бенуа не знал или забыл о том, что оранжерея с Лестницей ста ступеней была возведена Ж. Ардуэн-Мансаром в 1684-1686 гг., т. е. на
60 лет позже событий романа «Три мушкетера» (1844), которые разворачиваются в 16251628 годах. Не исключено, что он сделал это неосознанно, под влиянием памяти о детстве. Таким образом, совпадение детских, литературных и натурных впечатлений предопределило замысел Бенуа.

На страницах романа-хроники «Людовик XIV и его век» А. Дюма изложил свой подход к истории и источникам, благодаря которому он создал свое произведение не «как памфлет, а портрет человека, каким он был в жизни» $[8$, c. 6]: «В наше время был изобретен новый способ писать историю, а мемуары частных лиц приоткрыли нам личную жизнь богов нашей монархии, и мы увидели, что эти боги, как и боги древности, ослепительные издали, теряют часть своего блеска, если проникнуть во мрак, окружающий некоторые стороны их жизни» $[8$, с. 5]. В свете этих слов Дюма представляется особенно важным круг чтения А. Бенуа по истории Франции 1905-1906 гг., когда он обратился к теме прошлого Версаля и его обитателей во всем ее многообразии.

Бенуа с семьей приехал в Париж в марте 1905 г., а уже в середине апреля он обратился к мемуарам Л. де Сен-Симона «Подлинные воспоминания герцога де Сен-Симона о царствовании Людовика XIV и эпохе Регентства». Воспоминания этого придворного уже сыграли большую роль в работе художника над образом Людовика XIV во время его первого двухлетнего пребывания во Франции в конце 1890-х годов. Бенуа почерпнул из мемуаров Сен-Симона сведения о старости короля, а цитату: «Le roi se promenait par tous les temps ...» («Король прогуливается в любую погоду...») использовал в качестве названия для двух рисунков из серии «Последние прогулки Людовика XIV» (1898, ГМИИ им. А.С. Пушкина; Одесский художественный музей). Вернувшись к теме прошлого Версаля и его обитателей почти десять лет спустя, он вновь обратился к этому важному для него источнику. Еще один любимый мемуарист А. Бенуа с конца 1890-х гг. - Ф. де Курсийон, маркиз де Данжо (Dangeau, 1638-1720). Показательно, что его Journal de la cour de Louis XIV («Дневник двора Людовика XIV») вновь привлек внимание художника. Любопытно, что Бенуа читал мемуары Данжо в библиотеке (свой 
экземпляр, купленный у букиниста в 1897 г. [5, с. 182], он, очевидно, оставил в Петербурге), совмещая чтение с изучением эстампов [4, c. 79].

Помимо этих хорошо знакомых источников, А. Бенуа уже в начале мая 1905 г., т. е. через два месяца после приезда во Францию, заинтересовался мемуарами Ш.П. Дюкло (Ch. P. Duclos, 1704-1772), историка и королевского историографа [12, с. 58]. Дюкло был автором целого ряда трудов и воспоминаний, причем последние написаны в легком и непринужденном стиле. Бенуа отметил в дневнике только имя этого автора, но тем не менее можно предположить, что его интерес вызвали Mèmoires secrets sur les règles de Louis $\mathrm{XIV}$ et XV («Секретные мемуары о царствовании Людовика XIV, регентстве и царствовании Людовика XV») Дюкло, изданные в конце XVIII столетия и переизданные во второй половине XIX века.

После лета 1905 г., проведенного в Бретани, семья Бенуа обосновалась в Версале. Художник постоянно находился рядом с любимым памятником, каждый день, а часто и два раза в день он отправлялся в парк на этюды, изучал историю ансамбля. Теперь его внимание обратилось на труды историка и публициста, заведующего историческим отделом Национального архива Ж. Мишле (J. Michelet, 1798-1874): «Читаю Michelet “Людовик XV” и “Людовик XVI”. Страшно разочарован, болтовня и сплетничанье», записал художник свои впечатления в дневнике 1 декабря 1905 г. [13, с. 120]. А. Бенуа, по всей вероятности, читал последний том, посвященный времени правления Людовика XV и Людовика XVI из 18-томного труда Мишле Histoire de France («История Франции», 1844-1867). Впечатление Бенуа о сочинении очень показательно: труды этого автора отличала субъективность оценок в интерпретации исторических событий. Очень интересно сравнение сочинения Мишле с романом Дюма «Ожерелье королевы», записанное в дневнике 5 декабря: «<...> Продолжаю Michelet [Мишле]. - У него “Collier de la Reine” [«Ожерелье королевы»] в совершенно ином освещении. "Хорошенькая" Valois [Baлуа] обелена, а представитель церкви Роган выставлен эскроком ${ }^{2}$ - Достается сильно королеве. Намек на лесбианство, на любовников. - Ожерелье остается у нее! Вот и верь историкам и истории» [13, с. 120].

Совсем иное впечатление на А. Бенуа произвели труды Л.-Э. Дюссье (L.-É. Dussieux, 1815 - 1894), историка и географа. Записи в дневнике художника зимой 1906 года наполнены свидетельствами его большого увлечения этим автором. «Дома засел за книгу Дюссье. Версаль страшно интересен», - записал Бенуа 3 января 1906 г. [4, с. 77]. На следующий день он изучал наружные покои версальского дворца «по Дюссье» [4, с. 77]. 12 января Бенуа продолжал «зачитываться Дюссье» [4, c. 78]. По всей видимости, это был двухтомный труд Le Château de Versailles. Histoire et description («Версальский дворец. История и описание», первое издание - 1881), подготовленный Дюссье. В книге представлена история создания дворцово-паркового ансамбля Версаля с большим количеством документов, воспоминаний, литературных фрагментов, а также иллюстраций. Также она содержит последовательное описание покоев дворца с фотографиями. Отдельная глава в первом томе посвящена крышам дворца (Les Toits), но это единственное отступление от его парадного образа на страницах обширного труда Дюссье. Однако изучения парадной стороны Версаля для Бенуа было недостаточно, он стремился узнать о жизни его обитателей, повседневной и самой обыденной. Этому способствовало его личное знакомство с руководителем музея Версаля П. Нолаком, благодаря которому Бенуа смог заглянуть в уголки, не предназначенные для широкой публики. Так, например, запись в дневнике художника за 10 марта 1906 г. свидетельствует: «Были у Нолака. Посетили комнаты Дюбарри, ванную Луи XV, комнату за Salon de M-me Adélaïde [Салоном г-жи Аделаиды], коридор у бывшей chaise percée [стул, обитый «продырявленным» материалом] (eе, hélas [увы], уже нет)» [4, с. 89].

В подобном внимании А. Бенуа к деталям, вроде бы и не заслуживающим внимания, можно видеть тоже своего рода «урок» А. Дюма, который вскользь изложил свое от-

\footnotetext{
${ }^{2}$ Эскрок (от фр. escroc) - мошенник.
} 
ношение к источникам на страницах романа «Людовик XIV и его век»: «Мы знаем, что эти толки (о беременности королевы Анны Австрийской. - A. 3.) недостойны страниц истории и не делаем им никакой веры, но передаем их только для того, чтобы показать, что в изучении истории мы ничем не пренебрегаем, что мы равно ознакомились с сочинениями Мезере, Левассёра, Даниэля, с остроумными записками Бассомпьера, Таллемана де Рео и Бриенна, с архивами библиотек и с уличными слухами» [8, с. 96]. «Уроки» Дюма распространились и на мемуары. Так, например, А. Бенуа в конце декабря 1905 г. начал читать Mèmoires de M-me du Haunet [13, c. 125]. Речь идет, по всей видимости, о записках Mèmoires de M-me du Hausset [дю Оссэ], камеристки маркизы де Помпадур, изданных в 1824 г., через двадцать лет после ее смерти. По желанию маркизы она присутствовала при ее галантных беседах с королем и записывала их содержание. Дневник Бенуа за 28 декабря свидетельствует, что он прочел из этих мемуаров «128 страниц. Разумеется, это “лакейская” проза, но масса любопытных сведений о знакомых» [13, с. 125].

В 1906 г. А. Бенуа создал акварель «Представление султанше» (частное собрание) - под этим названием она была впервые опубликована в третьей книжке журнала «Аполлон» за 1909 год (рис. 3). В ней изображены (по колено) на очень близком переднем плане трое мужчин и женщина европейской внешности и в европейском костюме XVIII в. с пудреными париками. Один мужчина представляет даме двух других, сцена происходит в парке Трианона на фоне Французского павильона.

Примечательно, что сам Бенуа считал эту акварель эскизом [14, с. 80]. В 1906 году зимой и в начале весны он много работал в Трианоне около Французского павильона - не только писал этюды, но и разрабатывал сюжет из прошлого этого дворца. Работа шла тяжело. «Утром сделал этюд маслом "Pavillon français” [«Французский павильон»] в Трианоне, днем сделал его акварелью», - записал художник в дневнике 30 января [4, с. 82], а 4 февраля он «начал на огромном полотне вид “Salon $<$ Pavillon> français“ [ «Французского салона $<$ павильона>»] в Трианоне» [4, с. 83]. Через две

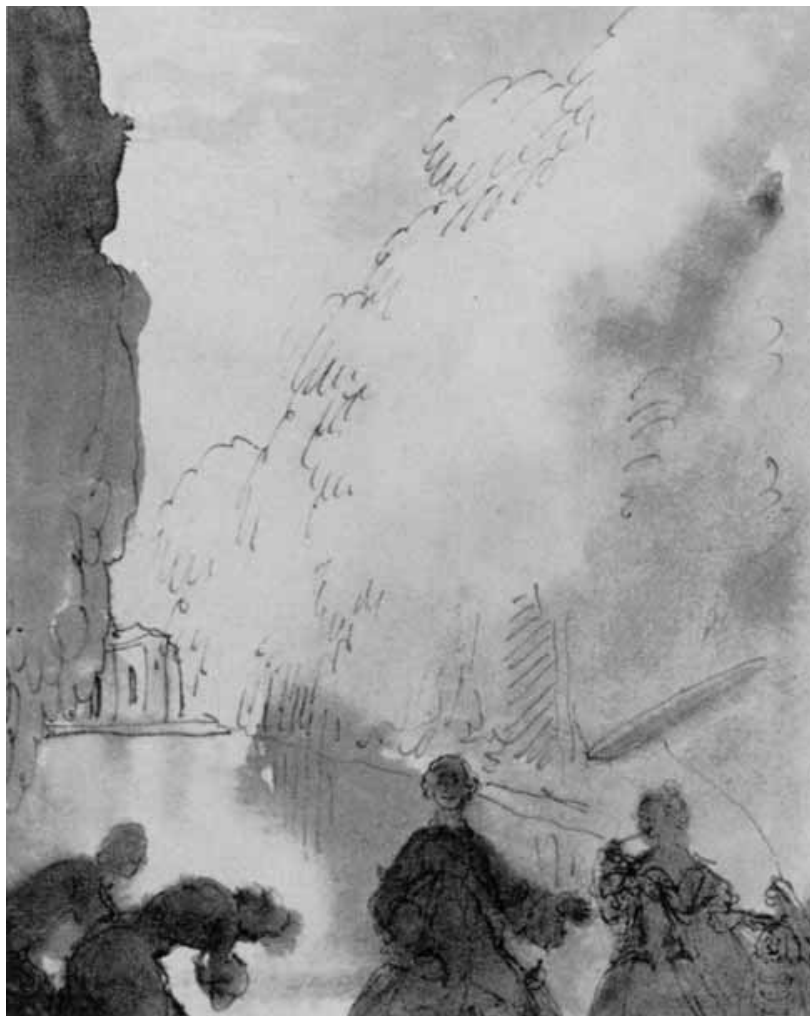

Рис. 3. А. Бенуа. Представление султанше. 1906. Бумага, акварель. Иллюстрация из журнала «Аполлон». 1909. №3

недели он снова принялся за этот мотив: «Сделал набросок рисунка "Pavillon français". Утром солнце, днем дождь, к закату опять проясняется», - свидетельствует запись за 20 февраля [4, с. 86]. На следующий день он вновь писал этюд, а 22 февраля занимался также историческим сюжетом: «Утром неудачно работал. Решил было замазать “Павильон”. Удержался, но все же удалил фигуры. Прострация» [4, с. 86]. Таким образом, можно видеть, что «фигуры» присутствовали в замысле художника на протяжении его работы над мотивом Французского павильона в 1906 году. Вероятно, в это время был создан эскиз акварелью «Представление султанше».

В марте 1906 г. Бенуа продолжил работать над своими произведениями, посвященными Французскому павильону. 6 марта 1906 г. он записал в дневнике: «Кончил давным-давно начатый этюд у “Французского павильона”. Днем по нему исправлял большую картину» [4, с. 88]. Судьба картины, а может быть, даже картин Бенуа с изображением Французского павильона сегодня неизвестна. Нельзя исключать, 
что она (или они) так и не были завершены. В то же время сюжет, изображенный в акварели «Представление султанше», он не оставил. В собрании художественного музея находится рисунок Бенуа в сложной графической технике из акварели и гуаши «Версаль», подписной и датированный 1907 годом [15, с. 61]. На нем изображена знакомая сцена представления кавалера даме в парке Трианона на фоне Французского павильона, только теперь эта сцена дана с очень далекой точки зрения, так что фигуры выглядят крошечными. Это впечатление усиливают очень высокие, в два раза выше дворца, боскеты, и вся сцена напоминает действие из спектакля в театре марионеток. Данный образ возникает неслучайно, так как Бенуа сравнивал в своих литературных работах придворных XVIII столетия с «фантошами» [16, с. 35-36]. Можно предположить, что на «театральное» решение рисунка «Версаль», который теперь смело можно назвать и «Представление султанше», оказала влияние работа Бенуа в 1907 г. над оформлением спектакля «Павильон Армиды» для Мариинского театра. Вероятно, тогда же акварельный эскиз «Представление султанше» художник подарил М. Фокину $[14$, с. 80], постановщику танцев, с которым познакомился и подружился во время работы над этим спектаклем, впоследствии оставив очень теплые воспоминания [5, с. 461-462] о нем.

Искать исторические прототипы сюжета «Представление султанше» вряд ли стоит, хотя Франция и Османская империя были союзниками против правителей Австрии Габсбургов еще с XVI в., когда Франциск I и Сулейман Великолепный заключили Франко-турецкий союз (1528), остававшийся в силе вплоть до вторжения Наполеона в Египет в 1798 году. При Людовике XIV турецкие послы стали частыми гостями в Версале, однако нет сведений о визитах туда султанш: их не было. В то же время султанши часто становились героинями произведений стиля тюркери (turqueries), популярного во Франции в середине XVIII века. Это произошло во многом благодаря деятельности Ш.-А. Ванлоо (Ван Лоо; Ch.-A. van Loo), автора множества картин на «турецкие» сюжеты [17, p. 32], в том числе десюдепортов «Султанша за вы- шиванием» и «Султанша, пьющая кофе» (оба полотна - 1755, Государственный Эрмитаж). Десюдепорты были выполнены для Турецкого будуара во дворце Бельвю (1748 - 1751, не сохранился), который маркиза де Помпадур построила как собственную резиденцию с целью утверждения своего общественного статуса. Ее обращение к «турецким» сюжетам не было случайным, так как они, особенно связанные с темой гарема, со времен Людовика XIV служили метафорой для возвеличивания или очернения королевских фавориток [18, p. 419]. Так, например, по мнению современных западных исследователей, в десюдепорте «Султанша, пьющая кофе» под видом султанши изображена маркиза де Помпадур [17, с. 32]. Поэтому можно утверждать, что Дюма совсем не случайно сравнил ее с султаншей на страницах своего романа-хроники «Людовик XV и его эпоха»: «<...> Она изобрела Олений парк. В первый раз фаворитка возымела мысль устроить для своего обожателя сераль. <...> Маркизу Помпадур мало беспокоили эти минутные рабыни, потому что она оставалась любимой султаншей, или, по крайней мере, Шехерезадой, долженствовавшей своим умом, искусством и сказками забавлять султана в продолжение тысячи и одной ночи» [19, с. 207]. Таким образом, в акварельном эскизе «Представление султанше» Бенуа изобразил маркизу де Помпадур в сцене из жизни придворных в Версале, при этом решающую роль в создании этого образа сыграли его впечатления от текста Дюма: свидетельства интереса художника к произведениям стиля тюркери сегодня неизвестны. Примечательно, что в труде А.Н. Бенуа «История живописи всех времен и народов», где Ш. Ванлоо лишь упомянут в примечании [20, с. 466, 467], этот аспект его деятельности никак не отмечен.

Суммируя приведенные выше наблюдения, можно заключить, что юношеские впечатления от романов А. Дюма, посвященных истории Франции XVII и XVIII столетий, сыграли важную роль в становлении образа Версаля и короля Людовика XIV в творчестве А. Бенуа конца 1890-х гг., повлияли на его поиски визуальных образов прошлого этого дворцово-паркового ансамбля в середине 1900-х годов. 


\section{Список источников}

1. Бенуа А.Н. Мои воспоминания : в 5 кн. Кн. 1-3. Москва : Наука, 1993. 711 с. (Лит. памятники).

2. Бенуа А.Н. Версаль // Версальские грезы Александра Бенуа. Русский музей представляет : альманах. Вып. 274. Санкт-Петербург : Palace Editions, 2010. $71 \mathrm{c}$.

3. Дурылин С.Н. Александр Дюма-отец и Россия // [Русская культура и Франция : в 3 т. Т. 2] : Т. 31/32. Москва : Журнально-газетное объединение, 1937. С. 491-562. (Литературное наследство).

4. Бенуа А.Н. Дневник 1906 года // Наше наследие. 2006. № 77. С. $72-104$.

5. Бенуа А.Н. Мои воспоминания : в 5 кн. Кн. 4-5. Москва : Наука, 1993. 743 с. (Лит. памятники).

6. Дюма А. Жозеф Бальзамо / [пер. с фр. И. Г. Русецкого и др.]. Москва : Альфа-книга, 2017. 1165 с. (Полное иллюстрированное издание в одном томе).

7. Завьялова А.Е. Произведения Арнольда Бёклина в творчестве Александра Бенуа // Вестник СПбГУ. Искусствоведение. 2018. Т. 8. № 3. С. $420-436$.

8. Дюма А. Людовик XIV и его век / [пер. с фр. Н. Щиглева и Е. Сутоцкой]. Москва : Альфа-книга, 2017. 780 с. (Полное иллюстрированное издание в одном томе).

9. Лансере Е.Е. Дневники : [в 3 кн.] Кн. 1: Воспитание чувств. Москва : Искусство-XXI век, 2008. $735 \mathrm{c}$.
10. Завьялова А.Е. Гравюры по рисункам Адольфа Менцеля в творчестве Александра Бенуа // Обсерватория культуры. 2018. Т. 15, № 1. С. 7481. DOI: 10.25281/2072-3156-2018-15-1-74-81.

11. Бенуа А.Н. Дневник. 1918-1924. Москва : Захаров, 2010.816 с.

12. Бенуа А.Н. Дневник 1905 года // Наше наследие. 2001. № 57. С. $48-78$.

13. Бенуа А.Н. Дневник 1905 года. Окончание // Наше наследие. 2001. № 58. С. 104-125.

14. Эрнст С.Р. Александр Бенуа. Петроград : Комитет популяризации худож. изд. при Рос. акад. истории материальной культуры, 1921.99 с.

15. Рязанский областной художественный музей : [альбом репрод.] / [авт.-сост. Т.Л. Щеглова]. Москва : Изобразительное искусство, 1978. 90 с.

16. Завьялова А.Е. «Игрушечный, кукольный, загадочный мир»: образы марионеток в творчестве Александра Бенуа // Артикульт. 2017. № 3 (27). C. 34-39.

17. Stein P. Madame de Pompadour and the harem images at Bellevue // Gazette des Beaux-Arts. 1994, janvier (Vol. CXXIII). P. 29-44.

18. Stein P. Amédée Van Loo's Costume turc: the French Sultana // The Art Bulletin. 1996. September (Vol. LXXVIII), № 3. P. 417-438.

19. Дюма А. Людовик XV и его эпоха : [роман]. Москва : ТЕРРА : Книжный клуб Книговек, 2016. $320 \mathrm{c}$.

20. Бенуа А.Н. История живописи [всех времен и народов]: [ч. 1. Пейзажная живопись] : в 4 т. Т. 3. Общая часть. Вып.16. Санкт-Петербург : Шиповник, 1912. С. 441-518.

\section{Alexandre Dumas's Works in the Art of Alexandre Benois}

\section{Anna E. Zavyalova}

Russian Academy of Arts, 21, Prechistenka Str., Moscow, 119034, Russia ORCID 0000-0003-2704-0486; SPIN 6024-1129 E-mail: annazav@bk.ru

Abstract. The article studies the problem of interpretation of literary source in visual creative work of A.N. Benois. There are identified and analyzed new sources of his works - historical novels by A. Dumas, père. The question about the role of the novels by Alexandre Dumas devoted to the history of France of the 17th and 18th centuries in creative work of Alexandre Benois has never become the object of research. The relevance of this article is determined by this fact. The scientific novelty of this article lies in revealing new literary sources of creative work of $\mathrm{A}$. Benois - Dumas's novels “Joseph Balsamo (Doctor's Notes)" (1846-1848), "Louis XIV and his Century" (1844), "Louis XV and his Epoch" (1849) and determining parallels between them and art practice of the artist: painting, graphics and art 
of book. The author analyses content of the artist's memories, his literary works, diaries, as well as diaries by E. Lanceray, and complements these information details by a comparative textological analysis of Benois's memoirs and Dumas's novels in Russian translations. This method allows to deepen the formal analysis of A. Benois's works (primarily the two Versailles series) and partially reveal the mechanism of complex figurative synthesis in the artistic consciousness at the turn of the 19th-20th centuries, on the basis of which they were created, to expand the existing perceptions about the literary sources of the artist's creative work. The author concludes that the novels by Dumas "Joseph Balsamo", "Louis XIV and his Century" had an influence on the artist's perception of the theme of court culture and Versailles in the historical, cultural and natural aspects. It was reflected in the appeal to the plot of "fish feeding" in the late 1890s, in the formation of the images of Versailles and King Louis XIV in old age. The article also finds that the novel "Joseph Balsamo" had an influence on Benois's creation of Trianon's everyday image in the past. At the same time, the artist turned to the interpretation of the image of Marquise de Pompadour as "sultana" under the influence of Dumas's novel "Louis XV and his Epoch". In addition, the three musketeers - characters of Dumas's novel with the same name - are placed in the drawing of the title page of Benois's "Versailles" album. It is important that it does not come about direct illustration of the novels, but about an artistic process of creating a figurative system of images and forming the artist's stylistics.

Key words: theory and history of art, art studies, art culture, Russian art of the late 19th - first part of the 20th century, A. Benois, landscape, modern, A. Böcklin, A. Dumas, Versailles, Trianon, Louis XIV, Marquise de Pompadour.

Citation: Zavyalova A.E. Alexandre Dumas's Works in the Art of Alexandre Benois, Observatory of Culture, 2019, vol. 16, no. 2, pp. 184-195. DOI: 10.25281/2072-3156-2019-16-2-184-195.

\section{References}

1. Benois A.N. Moi vospominaniya: $v 5$ kn. [My Memories: in 5 books], book 1-3. Moscow, Nauka Publ., 1993, $711 \mathrm{p}$.
2. Benois A.N. Versailles, Versal'skie grezy Aleksandra Benua. Russkii muzei predstavlyaet: al'manakh [Versailles Dreams of Alexandre Benois. Russian Museum Presents: almanac], issue 274. St. Petersburg, Palace Editions Publ., 2010, 71 p. (in Russ.).

3. Durylin S.N. Aleksandr Dyuma-otets i Rossiya [Alexandre Dumas-père and Russia], vol. 31/32. Moscow, Zhurnal'no-Gazetnoe Ob"edinenie Publ., 1937, pp. 491-562.

4. Benois A.N. Diary of 1906, Nashe nasledie [Our Heritage], 2006, no. 77, pp. 72-104 (in Russ.).

5. Benois A.N. Moi vospominaniya: $v 5 \mathrm{kn}$. [My Memories: in 5 books], book 4-5. Moscow, Nauka Publ., 1993, 743 p.

6. Dumas A. Zhozef Bal'zamo [Joseph Balsamo]. Moscow, Al'fa-Kniga Publ., 2017, 1165 p.

7. Zavyalova A.E. The Works of Arnold Böcklin in the Art of Alexander Benois, Vestnik SPbGU. Iskusstvovedenie [Bulletin of the Saint Petersburg State University. Arts], 2018, vol. 8, no. 3, pp. 420436 (in Russ.).

8. Dumas A. Lyudovik XIV i ego vek [Louis XIV and his Century]. Moscow, Al'fa-Kniga Publ., 2017, 780 p.

9. Lanceray E.E. Dnevniki. Kn. 1: Vospitanie chuvstv [Diaries. Book 1: Education of the Senses]. Moscow, Iskusstvo-XXI Vek Publ., 2008, 735 p.

10. Zavyalova A.E. Engravings Based on Adolph Menzel's Drawings in the Works of Alexander Benois, Observatoriya kul'tury [Observatory of Culture], 2018, vol. 15, no. 1, pp. 74-81 (in Russ.). DOI: 10.25281/2072-3156-2018-15-174-81.

11. Benois A.N. Dnevnik. 1918-1924 [Diary. 1918 1924]. Moscow, Zakharov Publ., 2010, 816 p.

12. Benois A.N. Diary of 1905, Nashe nasledie [Our Heritage], 2001, no. 57, pp. 48-78 (in Russ.).

13. Benois A.N. Diary of 1905. End, Nashe nasledie [Our Heritage], 2001, no. 58, pp. 104-125 (in Russ.).

14. Ernst S.R. Alexandre Benois. Petrograd, Komitet Populyarizatsii Khudozhestvennykh Izdanii pri Rossiiskoi Akademii Istorii Material'noi Kul'tury Publ., 1921, 99 p. (in Russ.).

15. Ryazanskii oblastnoi khudozhestvennyi muzei [Ryazan Regional Art Museum]. Moscow, Izobrazitel'noe Iskusstvo Publ., 1978, 90 p.

16. Zavyalova A.E. "Toy, Puppet, Mysterious World”: Images of Puppets in the Works of Alexander Benois, Artikul't [Articult], 2017, no. 3 (27), pp. 3439 (in Russ.). 
17. Stein P. Madame de Pompadour and the harem images at Bellevue, Gazette des Beaux-Arts, 1994, January (vol. CXXIII), pp. 29-44.

18. Stein P. Amédée Van Loo's Costume turc: the French Sultana, The Art Bulletin, 1996, September (vol. LXXVIII), no. 3, pp. 417438.
19. Dumas A. Lyudovik XV i ego epokha [Louis XV and his Epoch]. Moscow, TERRA Publ., Knizhnyi Klub Knigovek Publ., 2016, 320 p.

20. Benois A.N. Istoriya zhivopisi:v 4t. T. 3. Obshchaya chast' [History of Painting: in 4 volumes. Volume 3. General Part], issue 16. St. Petersburg, Shipovnik Publ., 1912, pp. 441-518.

\section{НОВИНКА}

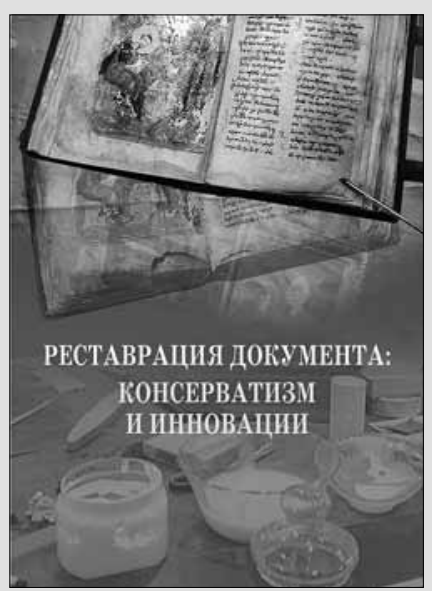

Реставрация документа: консерватизм и инновации : сборник статей / сост. А.А. Кащеев. Москва : Пашков дом, 2019. 156 с. : ил.

Сборник подготовлен к Международному научно-практическому семинару «Реставрация документа: консерватизм и инновации» (9-11 апреля 2019 г.), ежегодно проводимому в Российской государственной библиотеке. Основной задачей семинара является повышение профессиональных знаний реставраторов и хранителей библиотечных, архивных и музейных фондов, способных при необходимости в дальнейшем передавать приобретенные на практических занятиях семинара навыки и знания.

В сборник вошли статьи, в которых представлены результаты научной и практической работы реставраторов, специалистов по превентивной консервации и исследователей материальной основы документа.

\section{Справки и заказ изданий:}

119019, Москва, ул. Воздвиженка, д. 3/5

Российская государственная библиотека,

Издательство «Пашков дом»

+7 (499) 557-04-70, доб. 25-72;

Pashkov_Dom@rsl.ru,Pashkov_Dom.Book@rsl.ru

http://store.rsl.ru/service/pashkov_dom 